\title{
The Toledo Qur'ān and Islamic Eschatology: Translating the Names of Hell in Aljamiado Literature
}

\author{
El Corán de Toledo y la escatología islámica: traducir \\ «infierno» en la literatura aljamiada
}

Roberto Tottoli

Università di Napoli L'Orientale, Italia

\begin{abstract}
The introduction of the Toledo Qur'ān states that the text in the Latin alphabet was copied from an Aljamiado translation. In fact, the translation of terms and expressions relating to hell shows some specific characteristics of Aljamiado literature, such as the privileged use of calques from Arabic and a preference for the term Jahannam, though the most quoted term al-nār ("fuego") is also attested. These characteristics are more evident when compared to Latin translations prior or contemporaneous to the Toledo Qur'ān. It is clear that in the translation of terms related to hell, these works display greater attention to Latin style and final result thus evidencing another perspective and consequently another audience.

The preference given to the term Jahannam is closely linked to the evidence emerging from the Aljamiado eschatological literature, where Jahannam is generally preferred to al-nār "fuego." This preference reflects more than specific characteristics of the literature of the Moriscos, an evolution of Muslim literature as a whole, which is reflected in the kind of literary materials circulating and trasmitted. Futher, along with this, Aljamiado literature on hell and also the Toledo Qur'ān reflect similar developments in the late medieval Muslim Arabic literature, and therefore also in eschatological traditions, in which Jahannam emerges
\end{abstract}

La introducción del Corán de Toledo dice que el texto en alfabeto latino se copió de una traducción aljamiada. De hecho, la traducción de términos y expresiones relacionadas con el infierno muestra algunas características muy especiales de la literatura aljamiada, como la preferencia por el uso de calcos del árabe o del término Ŷahannam, aunque el término más citado, al-nār ("fuego"), está también atestiguado. Estas características son incluso más evidentes cuando se comparan con las traducciones latinas previas o contemporáneas al propio Corán de Toledo. Parece claro que estas obras conceden mayor atención al estilo latino en la traducción de términos relacionados con el infierno, lo que indica que tenían una nueva perspectiva $y$, consecuentemente, debían buscar otra audiencia.

La preferencia dada al término Ŷahannam está íntimamente relacionada con los casos encontrados en la literatura escatológica aljamiada, en la que Ŷahannam se suele preferir a $a l-n \bar{a} r$ (fuego). Pero más que una característica de la literatura de los moriscos, esta preferencia muestra una evolución de la literatura musulmana en general, tal y como queda reflejado en los materiales literarios que circulaban y se transmitían. Por tanto, en esta línea, la literatura aljamiada y el Corán de Toledo muestran desarrollos similares en la literatura árabe me 
strongly as the term used to describe hell in narratives.

Key words: Islam; Qur'ān translation; Aljamiado; Eschatology; Hell. dieval y, por tanto, en las tradiciones escatológicas en las que Ŷahannam emerge fuertemente como el término utilizado en la narrativa para describir el infierno y sus muchas etapas.

Palabras clave: Islam; traducción del Corán; Aljamiado; Escatología; Infierno.

\section{Introduction}

Among the medieval and early modern translations of the Qur'ān, the Toledo Qur'ān stands out with a few unique features. Translated into Spanish at the beginning of the $17^{\text {th }}$ century, it is not only a significant early attestation of a complete translation of the Muslim holy text into a European language, but also the work of a Muslim translator for a Muslim audience. Therefore, the Toledo Qur'ān is a translation which lies on the border between Europe and the Muslim world. It testifies to the activity of the translators of the Qur'ān across Europe, which started in the Iberian peninsula - especially in Spain - in the $12^{\text {th }}$ century. Likewise, it can be regarded as a product of Morisco literary activity, characterized by an activity of translation whose most typical expression was Aljamiado literature. In order to better appreciate the peculiarity of this translation in relation to this double context, I deemed it useful to analyze the terminology used to mention hell in the Qur'ān, and the way it is translated, discussing this specific aspect in relation to other Qur'ān translations and to Aljamiado literature as a whole. Through this analysis, I hope to be able to illustrate some significant features of this translation, and its relation to Aljamiado and Islamic literatures.

The choice of this topic is connected to a study I carried out on eschatological narratives regarding hell in Aljamiado literature. In another paper, I discussed the contents of the narratives in which hell is mentioned and described. ${ }^{1}$ Eschatological details and direct references to hell are in fact ubiquitous in many texts written by Moriscos. From the "Tale/story/Hadith of the Day of Judgment" to other well-known Islamic motifs or stories such as the night journey and the ascension to heaven ( $m i$ ' $r \bar{a} j$ ) by Muhammad, or the stories of the colloquy between Moses and God, of Jesus and the skull, of the Donzella Carcayona, and others - various Aljamiado texts

${ }^{1}$ See Tottoli, "The Morisco Hell: Significance and Relevance of the Aljamiado Texts for Muslim Eschatology and Islamic Literature." 
mention hell, or describe it in detail, defining it with different names and terms. Significantly, details and textual evidence of these stories show that the Aljamiado hell is perfectly in line with the Islamic descriptions, and closely related to Quranic and Hadith images. Where some small detail is added, it is perfectly consistent with the reinterpretation of Islamic literature during the Middle Ages. Furthermore, the existence of families and of several copies of the same narrative in Aljamiado versions attest a more conservative attitude towards the translated texts if compared to the body of Arabic versions which I was able to consult.

With this in mind, the translation of the terms and description of hell in the Toledo Qur'ān is certainly a significant aspect, which could shed further light both on this text, and on the analysis of the religious terms used in Aljamiado literature. Islamic terminology in Aljamiado literature, along with the discussion on the contents of the narratives is, in fact, the other main issue concerning the translation of Aljamiado literature, and its relationship with Islamic Arabic literature.

\section{The Toledo Qur'ān and Western Translations of the Qur'ān on Muslim Hell}

The Toledo Qur'ān is a complete translation of the Islamic holy text into Spanish, which has survived in one single manuscript preserved in the Biblioteca de Castilla-La Mancha in Toledo (no. 235). The text has been comprehensively studied and recently re-edited by Consuelo LópezMorillas, who has carried out various studies on the Aljamiado Qur'āns, and on this text in particular. ${ }^{2}$ Besides mentioning previous studies, in her edition of the Toledo Qur'ān, López-Morillas also examines the most recent research on this subject, providing a general overview on the Qur'ān in Aljamiado literature, and on the questions posed by this text. Copied in 1606 by an anonymous Morisco from Aragon (or supposedly Muhammad Rubio, as suggested by López-Morillas), the Toledo Qur'ān is a complete translation of the Qur'ān in Latin characters. As the text itself states, it was copied from an original which included the holy text in both Arabic and Aljamiado. ${ }^{3}$ The identity of the author of this translation, as well as

${ }^{2}$ López-Morillas, El Corán de Toledo. Edición y estudio del manuscrito 235 de la Biblioteca de Castilla-La Mancha.

${ }^{3}$ López-Morillas, El Corán de Toledo, pp. 13, 21 f. 
its relation to the lost Qur'ān by Yça de Segovia, who translated the text in 1456 - have been questioned by López-Morillas, and dismissed in another recent study by Ulli Roth and Reinhold Glei. ${ }^{4}$ As regards the translation itself, in her introduction, López-Morillas exhaustively discusses the main linguistic features of the text, focusing on flaws, traits and peculiarities in syntactic, morphological and lexical choices. ${ }^{5}$

There are different possible ways to analyze a Quranic translation, and many are the questions arising from the various perspectives. One interesting aspect is the analysis of the choices of the translator concerning specific topics, to be considered not only in relation to other translations of the Qur'ān, but also to literature as a whole. In this paper, I will make reference to the other Medieval and Early Modern European translations of the Qur'ān, and to Aljamiado literature. ${ }^{6}$ For the purpose of this study, the analysis of the way the names and the descriptions of hell are translated in the Toledo Qur'ān may prove to be extremely useful, given the relevance of the topic in the holy text, and the questions connected to it. Hell is in fact mentioned in many passages, mostly with the term al-nār, meaning "fire," and with Jahannam, which is the Arabic for Gehenna. Among the other names or expressions, there is the more frequent al-Jahim, along with other terms (Sa 'ìr, Lazāa, al-Huțama, al-Hāwiya) which, in some cases, puzzled exegetes and consequently translators as regards their exact meaning related to fire, flames, etc.

In the Toledo Qur'ān the most common term al-nār is translated as fuego, i.e. Spanish "fire." In fact, all the occurrences of the term al-nār, without exception, are translated in this way. ${ }^{7}$ As regards the translation

${ }^{4}$ López-Morillas, El Corán de Toledo, p. 33, underlines that, at the beginning, the copyist of the Toledo Qur'ân states that he copied into Latin script starting from an Aljamiado (i.e. in Arabic script) copy, while Yça de Segovia might have written his translation directly in Latin script. On this, see Roth and Glei, "Die Spuren der lateinischen Koranübersetzung des Juan de Segovia - alte Probleme und ein neuer Fund," who dismissed the possibility of a connection between the Toledo Qur'ān and the translation by Yça de Segovia.

${ }^{5}$ López-Morillas, El Corán de Toledo, p. 83f.

${ }^{6}$ The other existing Aljamiado translations are incomplete and, in general, refer to different traditions and only have few elements in common with the Toledo Qur'ān, see López-Morillas, El Corán de Toledo, pp. 46-81, and also López-Morillas, "The genealogy of the Spanish Qur'ān."

${ }^{7}$ López-Morillas, El Corán de Toledo, p. 140 (Q 2:24), p. 142 (Q 2:39), p. 145 (Q 2:80-81), p. 149 (Q 2:126-127), p. 150 (Q 2:174-175), p. 157 (Q 2:201), p. 159 (Q 2:217), p. 159 (Q 2:221), p. 163 (Q 2:257), p. 165 (Q 2:266), p. 166 (Q 2:275), p. 168 (Q 3:10), passim.

Al-Qanțara XXXV 2, 2014, pp. 527-553 ISSN 0211-3589 doi: 10.3989/alqantara.2014.018 
of the second most frequent term, Jahannam, the Toledo Qur'ān displays one of the most common features of Aljamiado literature - that is, the use of calques from Arabic for significant religious terms. All the occurrences of the Arabic Jahannam are translated as chehannam. ${ }^{8}$ This term also appears in the expression "fire of Jahannam," attested in some verses, which is always rendered as fuego de chehannam. ${ }^{9}$ Although the translation of the two main Quranic terms is consistent and systematic, chehannam seems to be preferred in some passages, and in the translation of other terms related to hell. Firstly, chehannam appears in relation to the translation and glossing of some verses where the term is not explicitly present in the Quranic text. ${ }^{10}$ Secondly, chehannam is the favorite choice when translating the other expressions in the Qur'ann related to hell, which exegesis and later narratives usually consider as different names of it. $\mathrm{Al}$ Jahim is mostly translated as chehannam ${ }^{11}$; only in a few cases it is translated as fuego ${ }^{12}$ or, in one case, adopting the calque of Arabic alchahim. ${ }^{13}$ The use of calques is also attested for the purpose of rendering other names, reflecting the Aljamiado tendency to preserve significant Arabic expressions from the original text. Even in this case, however, along with the transcription of the Quranic terms, the favorite choice appears to be chehannam, and not the more frequent Quranic fuego. In the

${ }^{8}$ López-Morillas, El Corán de Toledo, p. 157 (Q 2:206), p. 168 (Q 3:12), p. 183 (Q 3:197), p. 189 (Q 4:55), p. 193 (Q 4:93), p. 194 (Q 4:97), p. 195 (Q 4:105), p. 196 (Q 4:121), p. 198 (Q 4:140), p. 200 (Q 4:169), p. 234 (Q 7:18), p. 248 (Q 7:179), p. 251 (Q 8:16), passim.

${ }_{9}^{9}$ López-Morillas, El Corán de Toledo, p. 259 (Q 9:35), p. 262 (Q 9:63), p. 262 (Q 9:68), p. 264 (Q 9:81), p. 266 (Q 9:109), p. 429 (Q 35:36), p. 492 (Q 52:13), p. 529 (Q 72:23), p. 551 (Q 98:6). See "Jahannam" and "Fire" occurring together: p. 251.

${ }^{10}$ See the verse dealing with the punishment of misbelievers (Q 3:88): chehannam appears in the translated text but not in the original Arabic, López-Morillas, El Corán de Toledo, p. 174; the same tendency appears when dealing with other details and elements of hell: ghayyan in Q 19:58 is glossed and explained as Gaye un bal de fuego en chehannam, see López-Morillas, El Corán de Toledo, p. 336.

${ }^{11}$ López-Morillas, El Corán de Toledo, p. 203 (Q 5:10), p. 356 (Q 22:51), p. 436 (Q 37:23), p. 437 (Q 37:55), p. 438 (Q 37:64), p. 438 (Q 37:68), p. 453 (Q 40:7), p. 473 (Q 44:47), p. 473 (Q 44:56), p. 492 (Q 52:18), p. 502 (Q 56:49), p. 504 (Q 57:19), p. 525 (Q 69:31), p. 530 (Q 73:12), p. 539 (Q 79:36), p. 539 (Q 79:39), p. 541 (Q 81:12), p. 542 (Q 82:14, but fuego de chehannam), p. 553 (Q 102:6).

${ }_{12}^{12}$ López-Morillas, El Corán de Toledo, p. 149 (Q 2:119), p. 210 (Q 5:86), p. 440 (Q 37:163) and cf. fuego in translating Q 37:97 (not in an eschatological setting), p. 542 (Q $83: 16)$.

${ }^{13}$ López-Morillas, El Corán de Toledo, p. 266 (Q 9:113). 
case of $S a$ ' $\mathrm{i} r$, along with la valle de Çayr (Q 22:4), ${ }^{14}$ or fuego (Q 34:12), ${ }^{15}$ the preferred translation is chehannam (Q 31:21, 35:6, 42:7, 67:5, 10, 11). ${ }^{16}$ Saqar is transcribed simply as Çacar, ${ }^{17}$ or glossed as el fuego de Çacar ${ }^{18}$ but, again, also translated as chehannam. ${ }^{19}$ As regards the other less frequent terms - along with the prevalent transcription from Arabic, such as in the case of Alhóttama ${ }^{20}$ and Alhéggüiyah ${ }^{21}$ - the Arabic Lazā in Q 70:15 is translated as chehannam.22

This situation can be partly compared to what is found in other Aljamiado partial translations of the Qur'ān. These texts show a tendency to give a clear-cut definition of hell in the Spanish translation, mentioning it with the terms "jahannam" and "fire." For instance, in one passage the Arabic al-nār, such as in the case of al-nār al-kubrā in Q 87:12, is translated as en el fuego mayor de jahannam. ${ }^{23}$ This tendency is mostly evident in relation to other terms or concepts connected to hell. Where there is mention of Sijjin, it is glossed and translated as qu-es la presión en jahannam. ${ }^{24}$ The use of Jahannam when the translator needs to include an exegetical hint to hell appears in some other passages: al- 'adhāb al-kabìr (Q 88:24) is translated as el tormento mayor de jahannam ("the great torment of Ja-

${ }^{14}$ López-Morillas, El Corán de Toledo, p. 352.

${ }^{15}$ López-Morillas, El Corán de Toledo, p. 422.

${ }^{16}$ López-Morillas, El Corán de Toledo, pp. 410, 427, 463 and 520 (here also chehannam from ar. Jahannam appearing in Q 67:6).

${ }^{17}$ López-Morillas, El Corán de Toledo, p. 531 (Q 74:26-27), p. 532 (Q 74:42).

${ }^{18}$ López-Morillas, El Corán de Toledo, p. 532.

${ }^{19}$ López-Morillas, El Corán de Toledo, p. 497 (Q 54:48).

${ }^{20}$ López-Morillas, El Corán de Toledo, p. 554 (Q 104:4-5).

${ }^{21}$ López-Morillas, El Corán de Toledo, p. 553 (Q 101:9).

${ }^{22}$ López-Morillas, El Corán de Toledo, p. 526.

23 "BRAH T19" (=Martínez de Castilla Muñoz, Edición, estudio y glosario del manuscrito aljamiado T19 de la Real Academia de la Historia), pp. 322, 550.

24 "Junta 9" (=Laureano García, Tradiciones musulmanas (Ms. IX de la Biblioteca de la antigua Junta para la Ampliación de Estudios de Madrid)), p. 219; Sijjīn is also quoted in "BNM 4953" (=Hegyi, Cinco leyendas y otros relatos moriscos (Ms. 4953 de la Bibl. Nac. Madrid)), pp. 124, 125. Even if it is rare, we must also mention the term zabanniya which appears for instance in Ms "Junta 9" in a version of the story of the Day of Judgement attributed to Ka'b, see "Junta 9," pp. 321, 323. A passage in "BNM 4953" suggests that there could have been some problems of comprehension of the proper meaning of the term indicating the angels of hell. There, the expression y sera lançado en Zabāniya, followed by an analogous expression where Jahannam is used, seems to point to it as the name of a place, while the original meaning must have been "being thrown amongst the angels Zabāniya"; see "BNM 4953," p. 204. 
hannam"), ${ }^{25}$ but also fire is used; 'adhāb al-sa 'ìr (Q 67:5) is translated as la pena del fuego ("the punishment of Fire"). ${ }^{26}$ There are two more passages, in the first of which al-Jahim is translated as jahannam, while in the second occurrence as fuego. ${ }^{27}$ The term al-ghassiya in Q 88:1 is also rendered with fuego ${ }^{28}$ in this case Jahannam and fire are used to mean hell. Other texts take a different direction; in the Qur'ān commentary discussed by Vernet, jahanna $(\mathrm{m})$ stands alone, with no indication of fire. ${ }^{29}$ In general, the various renderings appear unsystematic, but point to the more common use of Jahannam and Fire, although there is a clear tendency to gloss and simplify. ${ }^{30}$ In general, the translation of the two major terms to indicate hell is faithful, i.e. Fire for al-nār and Jahannam for jahannam, but when there is a need to insert glosses or further explanation, Jahannam and Fire are sometimes used interchangeably, while other times Jahannam is preferred.

In this regard, and in relation to these other partial translations from Aljamiado literature, the Toledo Qur'ān seems to display similar features, using the two most common terms Jahannam and Fire (al-nār) for the most part. However, even more than in these translations, Jahannam, in the form chehannam - which is a calque from Arabic and not of the Biblical Gehenna - seems to be the favorite term. This, as we shall see, attests to the use of this term in Aljamiado sources, and stands out in comparison to the other Western translations. A brief comparison of the Aljamiado translation to some of the early and coeval translations into Latin will suffice to better understand its main features.

In the Bibliander edition of the translation by Robert of Ketton, for instance, where it is possible to trace the verses, gehenna is given as the corresponding translation of the Arabic Jahannam in most passages, but it is

25 "BRAH T19," p. 324.

26 "BRAH T19," pp. 337-338; see also p. 338: aṣhāb al-sa 'ìr transl.: conpañas del fuego.

27 "BRAH T19," p. 347.

28 "BRAH T19," p. 551.

${ }^{29}$ Vernet, "La exegesis musulmana tradicional en los coranes aljamiados," pp. 135137; in the passage at p. 135 pena de fuego is mentioned just after the term jahannam.

${ }^{30} \mathrm{Cf}$. in fact the tables of the various translations made by López-Morillas, The Qur'ān in Sixteenth-Century Spain: Six Moriscos Versions of Süra 79: al-jahìm is rendered as fuego or alternatively jahannam, pp. 78, 79. In the exegetical parts chehannam appears alternatively as fire to refer to hell, see López-Morillas, El Corán de Toledo, pp. 321, 336, 373 , see also p. 413 where Jahannam is inserted just after al-nār, which is rendered in the same verse as fire (Q 32:19); but cf. p. 396: fuego, p. 407: alchanna / fuego. 
also translated as infernus, ${ }^{31}$ and even as ignis. ${ }^{32}$ At the same time, al-nār is translated as ignis all over the text. Interestingly, this translation highlights the different approach and focus of a non-Muslim translator, who was more concerned about the final result of the Latin version. Rather than a matter of inconsistency, there seems to be a problem of comprehensibility of the Latin text, resulting in the choice of terms belonging to Biblical tradition. A clear example of this is the translation of all the other terms connected to hell: ignis (or alternatively focus, which is never connected to al-när), Gehenna and infernus are used alternatively. ${ }^{33}$

Similar cases of calques from Arabic can be found in some passages of Egidio da Viterbo's translation: Alchumatu of al-Hutama in Q 104105, and al-Giazim of al-Jahim. ${ }^{34}$ However, where the two occurrences of al-Hutama appear together, the puzzling term is given as "infernum, Alchumatu"; 35 as regards al-Jahìm, it appears in other occurrences alternatively as ignis ${ }^{36}$ or, preferably, in the second part of the Qur'ān, as infernus. ${ }^{37}$ Different solutions are also adopted to render $S a$ ' $\mathrm{i} r$, which is translated or transcribed as Zangris/Zaigr, ${ }^{38}$ or as infernus, ${ }^{39}$ and even

${ }^{31}$ Bibliander, Machumetis Saracenorum principis, eiusque successorum vitae, doctrina, ac ipse Alcoran (1 ${ }^{\text {st }}$ ed. 1543), p. 76 (Q 11:119), p. 85 (Q 15:43), pp. 91, 94 (Q 17:8, 17:97, while in the rest of the süra the term is translated as "gehenna"), p. 98 (Q 18:102), p. 100 (Q 19:86), p. 142 (Q 38:85), p. 144 (Q 39:71), p. 154 (Q 45:10), p. 160 (Q 50:24, 30), p. 165 (Q 55:43), p. 181 (Q 78:21).

${ }^{32}$ Bibliander, Machumetis Saracenorum, p. 153 (Q 74), p. 178 (Q 72:15, 23), p. 184 (Q 85:10).

${ }^{33}$ Ignis; for al-Jahìm in Bibliander, Machumetis Saracenorum, p. 42 (Q 5:86), p. 67 (Q 9:113), p. 109 (Q 22:51), p. 118 (Q 26:91), p. 139 (37:68), passim; see also p. 154 (Q 44:56): foco, p. 183 (Q 82:14): focum, p. 187 (Q 102:6): foci. For Sa îr: Bibliander, Machumetis Saracenorum, p. 107 (Q 22:4), p. 129 (Q 31:21). For Saqar: Bibliander, Machumetis Saracenorum, p. 164 (Q 54:48, but it is focum), p. 179 (Q 74:26-27), p. 179 (Q 74:42). For Lazāa: Bibliander, Machumetis Saracenorum, p. 177 (Q 70:15). Gehenna: for al-Jahìm: Bibliander, Machumetis Saracenorum, p. 139 (Q 37:23, 64). For Sa ìr: Bibliander, Machumetis Saracenorum, p. 149 (Q 42:7). Infernus: for Sa ìr: Bibliander, Machumetis Saracenorum, p. 174 (Q 67:10,11).

${ }^{34}$ Starczewska, Latin Translation of the Qur'ān (1518/1621) commissioned by Egidio da Viterbo. Critical Edition and Introductory Study, p. 342 (Q 22:51), p. 371 (Q 26:91).

${ }^{35}$ Starczewska, Latin Translation of the Qur'ān, p. 698.

${ }^{36}$ Starczewska, Latin Translation of the Qur'ān, p. 27 (Q 2:119), p. 133 (Q 5:10), p. 148 (Q 5:86), passim.

${ }^{37}$ Starczewska, Latin Translation of the Qur'ān, p. 442 (Q 37:23), p. 445 (Q 37:64, 68), p. 451 (Q 37: 163), p. 477 (Q 40:7), passim.

${ }^{38}$ Starczewska, Latin Translation of the Qur'ān, p. 337 (Q 22:4: Zangris), p. 411 (Q 31:21), p. 425 (Q 34:12).

${ }^{39}$ Starczewska, Latin Translation of the Qur'ān, p. 430 (Q 35:6), p. 498 (Q 42:7), p. 624 (Q 67:5), p. 625 (Q 67:10), p. 626 (Q 67:11). 
ignis, while Lazā is ignis ardens, ${ }^{40}$ and Saqar and al-Hāwiya are translated as infernus. ${ }^{41}$

In general, however, al-nār is always translated as ignis while Jahannam as infernus. The translation thus reflects the expected problems posed by the meanings of the various names of hell, showing a preference for infernus. It is somehow clear that the translator, whenever he is not able to find an exact equivalent for one term, opts for the term which can best recall hell in the target culture of the translated text. This is also evident in other coeval or slightly later translations, despite the different solutions adopted to render Jahannam. While, for example, in the Latin translations by Germanus de Silesia and Cyril Lucaris al-nār is always translated as ignis, the former translates Jahannam alternating infernus with a more frequent gehenna, while the latter always translates it as infernus. ${ }^{42}$ In Lucaris infernus is his favorite solution for translating al-Jahim. ${ }^{43}$ Infernus is also the favorite solution by Germanus for translating al-Jahim ${ }^{44}$ while he opts for different solutions to translate this term as well as other less frequent names. ${ }^{45}$

Although it must be clear that the matter at stake here is not the relation between these translations, this brief comparison points out that the Toledo Qur'ān appears first of all systematic in the translation of the two main terms for hell, in the use of chehannam for Jahannam, and also as regards other less frequently quoted terms. Many other significant Islamic terms are transcribed from Arabic in the Qur'ān, not only when they are related

${ }^{40}$ Starczewska, Latin Translation of the Qur'ān, p. 635 (Q 70:15).

${ }^{41}$ Starczewska, Latin Translation of the Qur'ān, p. 646 (Q 74:26-27), p. 647 (Q 74:42), p. 695 (Q 101:9).

${ }^{42}$ See for ex. Cruz Palma, La traducción latina del Corán atribuida al Patriarca de Constantinopla Cirilo Lúcaris (1572-1638), p. 19 (Q 2:206: Infernus), passim; Germán de Silesia, Interpretatio Alcorani Litteralis. Parte I: la traducción latina; introducción y edición crítica, ed. García Masegosa, p. 56 (Q 2:206: gehenna), p. 65 (Q 3:12: infernum).

${ }^{43}$ Cruz Palma, La traducción latina del Corán, p. 13 (Q 2:119), p. 40 (Q 5:10: ignis infernalis), p. 169 (Q 22:51), p. 187 (Q 26: 91).

${ }^{44}$ Germán de Silesia, Interpretatio Alcorani Litteralis, p. 49 (Q 2:119), p. 101 (Q 5:86), p. 128 (Q 7:41), p. 141 (Q 7:179), passim.

${ }^{45}$ Germán de Silesia, Interpretatio Alcorani Litteralis, on other translation of al-Jahìm: p. 165 (Q 9:113: gehenna), p. 337 (Q 37:23: Tartari), p. 339 (Q 37:97: ignis ardentis), p. 341 (Q 37:163: ignis inferni), p. 353 (Q 40:7: tormento tartari), p. 374 (Q 44:47, 56: Tartari), p. 399 (Q 52:18: supplicio orti), p. 413 (Q 56:94: ardentem barathri), p. 442 (Q 69:31: tartarum), p. 462 (Q 79:39: barathrum). Sa ì $r$ : p. 363 (Q 42:7: ignem), p. 437 (Q 67:5, 10, 11: ignis, flamma, ignis). Saqar: p. 404 (Q 54:48: ignem), p. 451 (Q 74:26-27: Tartari... ignis), p. 452 (Q 74:42: barathrum Saccara). Lazā: p. 443 (Q 70:15: Agape... flamma). al-Hāwiya: p. 505 (Q 101:9: barathrum). al-Huțama: p. 511 (Q 104:4-5: orci infernalis). 
to eschatology (i.e. alchanna for paradise). The use of chehannam, however, does not just illustrate the central concern of an Islamic translation - not only in comparison to the other European translations of the Qur'ān - but also a clear tendency to further emphasize the Islamic character of the terminology. This is more evident in the Toledo Qur'ân than in any other Aljiamiado translation. However, as we shall see, it is not a specific feature of this Quranic translation, but is strictly connected to Aljamiado. In order to support this statement, we will briefly analyze Aljamiado literature in the following paragraph.

\section{From Arabic to Spanish. The Names of the Muslim Hell in Aljami- ado Literature}

Hispanists and scholars of Aljamiado texts have carried out numerous studies on the linguistic questions raised by these texts, especially if relevant to the history of Iberian languages and vernaculars of the periods they were written in. The present analysis will rather focus on how Spanish writers or copyists translated Islamic eschatological words and concepts into Spanish, in particular regarding the Muslim Hell, so as to better understand the choices made by the translator of the Toledo Qur'ân.

Aljamiado and Morisco literature is Islamic literature written in Iberian languages between the $15^{\text {th }}$ and the $17^{\text {th }}$ centuries and - as it has been rightly defined - it is mainly based on faithful translations of original Arabic works. ${ }^{46}$ This faithfulness is undoubtedly related to the necessity to preserve the essence of the original, but also to characterize the specificity of these texts with Arabisms and formal devices. ${ }^{47}$

\footnotetext{
${ }^{46}$ The connection of the Aljamiado texts with the Arabic originals is still awaiting comprehensive discussion and research. The locus classicus on this point is the $\mathrm{PhD}$ thesis by L.P. Harvey, The Literary Culture of the Moriscos, 1492-1609: A Study Based on the Extant Manuscripts in Arabic and Aljamía. Using the words by Alberto Montaner, these translations were made with gran fidelidad; see Montaner Frutos, "La Aljamía: una voz islámica en Aragón," p. 100; on the point see also Barletta, Gestos clandestinos: la literatura aljamiado-morisca como práctica cultural, p. 119; Reuter, Aljamiado narratives of Muhammad's ascension to heaven: the Moriscos and the mi'raj, p. 10; López-Baralt, Tratado de los dos caminos: (ms. S2 de la Colección Gayangos, Biblioteca de la Real Academia de la Historia) por un morisco refugiado en Túnez, pp. 163-164; Suárez García, "Las demandas de Hatim al-'Așam: una traducción de Algazel y otras versiones morisca" (forthcoming).

${ }^{47}$ On the topic of Arabism and style as a cultural reference in texts not translated from Arabic, see Harvey, Muslims in Spain 1500 to 1614, p. 141.
} 


\subsection{Jahannam}

This necessity to preserve the original and further characterize significant Islamic words emerges in the terminology used to mention hell and its features. This is in fact a significant example of the ways Aljamiado texts read, translate and interpret the corresponding Arabic terms for their audience. As already noticed in other studies, the first evidence is that $J a$ hannam is also in this case the preferred term to mention hell, rather than the corresponding fuego ("fire"). Fuego translates the Arabic al-nār, which is the most common term in Islamic Arabic literature but appears in Aljamiado texts as second in frequency after Jahannam. ${ }^{48}$ Jahannam appears as the most common name to mention hell in various passages in the texts taken into consideration, alone ${ }^{49}$ or alongside aljanna, which is the Aljamiado loanword from the Arabic al-janna, the most frequent name of paradise in the Qur'ān and Muslim traditions. ${ }^{50}$ The transliteration of aljanna for

${ }^{48}$ The proportion already appears in the Qur'ān, where Jahannam is mentioned 77 times, while fire is mentioned, apart from the occurrences in its first meaning, about 125 times; see Gwynne, "Hell and Hellfire," in Encyclopedia of the Qur'ān, p. 414.

49 "Paris 774" (=Sánchez Álvarez, El manuscrito misceláneo 774 de la Biblioteca nacional de Paris), pp. 166-168, 170, 182, 202, 226-27, 263: tormento de jahannam, pp. 275-277; "Aitona" (=Roza Candás, Narraciones aljamiado-moriscas en el manuscrito de Aitona), p. 292; "Junta 57" (=Mauries Boumehdi, Miscelanea aljamiada narrativa y doctrinal: edicion y estudio del manuscrito Junta 57 del CSIC Madrid), f. 99r, 102r, 109r; "BRAH T19," pp. 348, 349: mentioning al 'adhab doloroso de jahannam; "BRAH T19," pp. 416, 419, 421, 423, 439, 445; "Junta 9," pp. 241, 354, 460; Wiegers, Islamic Literature in Spanish and Aljjamiado. Yça de Segovia (fl. 1450), his Antecedents and Successors, pp. 252, 255, 262f.; "ABN 614” (=Bouras, La Wașiyya de 'Alī del Manuscrito Aljamiado 614 de la Bibliothèque Nationale de Argelia [Estudio, Edición y Materiales]), pp. 355, 366; Mancebo de Arévalo, Sumario de la relación y ejercicio espiritual sacado y declarado por el Mancebo de Arévalo en nuestra lengua castellana, pp. 179, 266, 271, 287, 302; "Junta 13" (=Códice aljamiado de varias materias (Manuscrito N. ${ }^{\circ}$ XIII de la Antigua Junta para la Ampliación de Estudios)), pp. 252, 289; Vespertino Rodríguez, Leyendas aljamiadas y moriscas sobre personajes bíblicos, pp. 181, 183, 254; "Urrea de Jalón" (=Corriente Córdoba, Relatos píos y profanos del manuscrito aljamiado de Urrea de Jalón), pp. 63, 202, 208, 270, 273; "Tulaytuli" (=La plegaria musulmana en el 'Compendio de al-Tulaytuli'. Transcripción del manuscrito de Sabiñan (Zaragoza)), p. 60.

50 "Junta 57," f. 25r bis, f. 49v; "Paris 774," p. 261; “Aitona," p. 234; "BRAH T19," p. 434; "Junta 9," p. 427; “Junta 13," pp. 350, 402; Vespertino Rodríguez, Leyendas aljamiadas, pp. 174, 175, 177, 205, 207, 224, 226; “Urrea de Jalón,” p. 81; Kontzi, Aljamiado Texte, pp. 681, 873; "BRAH T8" (=Guijarro Hortelano, La maternidad en las comunidades mudéjar y morisca según un manuscrito aljamiado-morisco aragonés. Estudio y edición crítica (Códice T-8, BRAH)), p. 461; "Tulaytuli," p. 64. López-Morillas, "Aljamiado and the Moriscos' Islamization of Spain," p. 18: aljanna and jahannam are always used instead of paraiso and infierno. 
paradise, including the article al-, also explains why jahannam appears as the most frequent term: it most probably looked much more "Islamic" from a religious point of view, as a way of differentiating among the surrounding non-Muslim people, surely much more than translating the Arabic word as paraiso or infierno, or a generic "fire." Furthermore, the couple aljanna and jahannam maybe had also a superficial phonetic resemblance which could have made them a convenient pair of contrasting terms.

As displayed in various religious texts containing description or mention of hell, Aljamiado literature shows a preference for Jahannam also in the range of expressions connected to the term. An interesting example is the use of the expression $f(f)$ uego de jahannam ("fire of Jahannam"). The corresponding Arabic expression nār Jahannam is already mentioned in the Qur'ān, ${ }^{51}$ and also appears in a number of major Arabic traditions. Early Quranic commentaries mostly mention it in connection to the related verses in Quranic passages, ${ }^{52}$ or while mentioning one of the hadiths - attributed to the Prophet Muhammad - which use this expression. Major hadith collections, for instance, include a few reports in which the Prophet Muhammad states that the "fire of Jahannam" awaits those who commit suicide with a knife, or by other means, such as by drinking poison, etc. ${ }^{53}$; or that the fire on earth is one seventieth of the "fire of Jahannam." ${ }^{54}$ Other hadiths, in differing versions, mention the fire of Jahannam when the Prophet states that the destiny awaiting the men drinking from golden or silver vessels is that "the fire of Jahannam will gargle in their bellies." 55 Similar reports can be found in the major hadith collections. ${ }^{56}$ However,

${ }^{51}$ See Q 8:37; 9:49, 68, 81, 109; 35:36; 52:13; 72:23; 89:23.

${ }^{52}$ See for instance Muqātil b. Sulaymān, Tafsìr, I, pp. 165, 567, II, p. 187, passim.

${ }^{53}$ Al-Bukhārì, Sahīh, II, p. 96 no. 1363, VII, p. 139 no. 5778, VIII, p. 26 no. 6105 , p. 133 no. 6652; Muslim, Sahīh, I, p. 103; Ibn Māja, Sunan, II, p. 1145 no. 3460.

${ }^{54}$ Al-Bukhārī, Sahīh, IV, p. 121 no. 3265; al-Tirmidhī, Sunan, IV, p. 710 no. 2540; Ibn Māja, Sunan, II, p. 1130 nos. 3413, 3415; Mālik, al-Muwatta', II, p. 994; Ibn Hazm, al-Fisal fi al-milal, II, p. 81, V, p. 40; Ibn Abī al-Dunyā, Sifat al-när, I, p. 99 no. 148, p. 102 no. 155.

${ }^{55}$ Al-Bukhārī, Sahīh, no. 5634; Muslim, Șahìh, III, p. 1634; Mālik, al-Muwatta', II, p. 924; al-Tha'labì, al-Kashf wa-l-bayān 'an tafsìr al-Qur'ān, II, p. 47, III, p. 264; Ibn Abì Shayba, al-Musannaf, V, p. 103 no. 24135.

${ }^{56}$ Muslim, Sahi h, I, p. 454, IV, p. 2184: the expression is in the title of a $b \bar{a} b$ on the heat of the fire of Jahannam. See also Ibn Abī al-Dunyā, Sifat al-nār, I, p. 99 no. 149: the fire of this world invokes protection from the fire of Jahannam. See how the "fire of Jahannam" quoted by Andalusian authors such as Ibn Hazm, al-Fisal, II, p. 81, III, p. 66, IV, pp. 55, 152, 154, V, p. 40; Ibn Abī Zamanīn, Usūl al-fiqh, I, p. 139; and Makkī b. Abì Ṭālib, al-Hidāya ilā bulūgh al-nihāya fì 'ilm ma 'ānì al-Qur'ān wa-tafsìri-hi, IV, p. 2368, VI, p. 4297, passim. 
Quranic passages and later sources in which the expression is attested appear to be mostly referring to the fire as belonging to hell, thus "the fire of Jahannam" is used in its literal meaning. The impression from the quotations in the Aljamiado texts is that in most cases the fuego de jahannam, the "fire of Jahannam," is quoted with a clear reference to hell and its punishment as a whole rather than to the fire which is awaiting the damned. ${ }^{57}$ This may be not the case when Muhammad asks God to save his community $($ al-umma $)$ from the fire of Jahannam, or in other occurrences. ${ }^{58} \mathrm{Ne}-$ verthless, it probably stands for hell in general when mention is made to those who are to be saved or to escape the "fire of Jahannam," 59 or to "those of the fire of Jahannam," a more probable translation of ahl Jahannam than ahl nār Jahannam. ${ }^{60}$

The preference for Jahannam to give a vivid picture of hell appears in a variety of other expressions which are in general derived from the original Arabic texts, but which also clearly indicate the characterization, and even popularization, of the description of hell. The terms and expressions are also in these cases already mentioned in hadith literature, but it is in late Medieval narrative rewritings that these elements are combined in colorful descriptions. In this regard, Aljamiado texts perfectly fit in this context, confirming this tendency towards enlargement and narrative reworking. The term Jahannam is used in many expressions to describe

57 “Paris 774," p. 137; “Aitona,” pp. 226, 229, 230; “Junta 57,” f. 97r; "BRAH T19," pp. 297, 304, 361; see also Ms Madrid BRAH S-I, cap. 16 in Latin characters as transcribed in “ABN 614," pp. 371, 372, 374; "BNM 4953," pp. 114, 122, 132, 158, 198, 201, 203, 204 , 222; “Junta 13," pp. 251, 259, 265; “Tulaytuli," pp. 63, 70; Valero Cuadra, La leyenda de la Doncella Carcayona. Estudio y edición crítica, p. 472. The expression sometimes appears with a secondary reference to its fire just to indicate "not to enter hell": "Paris 774," p. 138; "BRAH T19," p. 374. On this point see also Roza Candás and Suárez García, "Léxico religioso islámico y cristiano en dos manuscriots aljamiados," p. 224, where they mention the "sintagma fuego de jahannam" used to translate the Arabic al-Jahim in some specific cases.

${ }^{58}$ There is no doubt that it also occurs where the punishment of proper fire - or even fires of Jahannam - are meant with these expressions; see for instance "Paris 774," p. 201: Fuegos; “Aitona," p. 291: fuego; "Paris 774," p. 205; “Aitona,” p. 293; “Junta 9," pp. 317, 321; “Junta 57," ff. 36v, 39r, 43v, 106v; cf. f. 48r: la pena de Jahannam; “Junta 9," p. 420; "Junta 13," p. 402. Jahannam alone is used in some passages alongside the expression "fire of Jahannam," see "Paris 774," pp. 159-160, 204, 213; “Aitona," p. 298; “Junta 9," p. 426; Mancebo de Arévalo, Sumario, p. 187; “Junta 13," pp. 258-259; Mancebo de Arévalo, Tratado (Tafsira), pp. 288, 289, 338, 373: los fwegos de Jahannam; “BRAH T8," p. 461.

59 "Paris 774," pp. 148, 159, 160, 260; "Junta 57," ff. 98r-98v, 111v, 132v, 142r; "BRAH T19," pp. 417, 446; Vespertino Rodríguez, Leyendas aljamiadas, pp. 191, 204; "Urrea de Jalón," p. 167; Kontzi, Aljamiado Texte, pp. 363, 445, 616, 640, 665 (Ms Madrid Junta no. 3).

${ }^{60}$ Vespertino Rodríguez, Leyendas aljamiadas, pp. 236, 238. 
hell, such as in las kadenas de jahannam ("the chains of Jahannam"), ${ }^{61}$ the perros de jahannam ("dogs of Jahannam"), ${ }^{62}$ and un árbol de jahannam ("a tree of Jahannam"). ${ }^{63}$ As regards animals inhabiting hell, the major role is undoubtedly that of the serpents and scorpions, and above all serpents (usually culebras) appear in frequent expressions to indicate punishments. ${ }^{64}$ A description, along with the puertas de jahannam ("doors of Jahannam"), of the culebras de fuego ("serpents of fire"), de las sierpes de jahannam ("of the serpents of Jahannam") is given in one sermon on the merits of Ramadan, in which the two terms are alternatively used. ${ }^{65}$ The list could be longer, as in many other expressions Jahannam appears as a key term in the pictorial description of hell and its punishments. ${ }^{66}$

The interrelationship between the various terms can be identified in the different versions of the same text. For instance, in the versions of the story of the Day of Judgment ascribed to Ka' $b$ al-Aḥbār, there is a passage in which the Angel of Death, describing the punishments of hell, mentions the tormento de los de al-jahim ("torment of those of the Jahim") ${ }^{67}$ in one manuscript, and in another the tormento de los de jahannam ("torment of

61 "Paris 774," pp. 161, 178: fuwego penoso; "BRAH T19," p. 418; “Junta 13,” p. 260.

62 "Paris 774," p. 190; “Aitona,” p. 285; “Junta 9," p. 305.

63 “Junta 13,” pp. 254, 292; “Urrea de Jalón,” p. 268.

${ }^{64}$ A long description of its serpents can be found in the Ms Urrea de Jalón: "Urrea de Jalón," p. 72. In the story of Buluqiyya, among the punishments and animals living there, the serpents of Jahannam (culebra(s)) are mentioned, see "Junta 57," f. 12r, and on the scorpions, see ff. $19 \mathrm{v}, 28 \mathrm{v}$.

65 "Junta 57," f. 107v; for a description of the culebras de jahannam, see "BRAH T8," p. 472.

${ }^{66} \mathrm{~A}$ frequent image is related to the orilla de jahannam ("ear of jahannam"), when Gabriel obeys to an order by God who told him to take hell and move it, so Gabriel gets near to its ear(s) to obey God, or it is said that the Prophet prostrates before it to intercede for the sinners among his people who are punished there; see "Paris 774," pp. 201, 208, 211; "Aitona," pp. 291-292, 295, 297 (slightly different and spelling orilas), see in fact also "Junta 9," p. 327; and cf. "Junta 57," f. 160v: los resollos de jahannam. For other espressions cf. also "Paris 774," p. 204: tizones de jahannam; "Paris 774," p. 206: xuelo de jahannam; "Junta 9," p. 319: espaldas de jahannam; "Urrea de Jalón," p. 266: alqasar en jahannam; "Junta 57," f. 150v: las mayors de jahannam; "Junta 57," f. 163r: las cuestas de jahannam; "Tulaytuli," p. 66: las puertas de jahannam; and cf. "Junta 9," p. 380: las siete puertas del fuego; Ms Madrid BRAH, Gay T13, cap. 16 trascribed in “ABN 614," p. 408: las gradas de jahannam. In other texts including descriptions of Jahannam, Mālik the keeper of hell is usually mentioned: for instance along with the $k(c)$ ubierta de jahannam: "Paris 774," p. 197; “Aitona," p. 289; “Junta 9," p. 313; see also "Paris 774," p. 208; "Aitona," p. 295; "Junta 57," ff. 157r, 167v, 169r. In other passages he is referred to as tesorero del ffuego, see "Paris 774," p. 206; “Aitona," p. 294: tresorero.

67 "Paris 774," p. 190. 
those of the Jahannam") ${ }^{68}$ then followed in both by the mention of the $\mathrm{Sa}$ ' $\mathrm{i} r$. These two manuscripts introduce slight variants as regards the identification and naming of hell. These differences - which can be the result of either a reduction or an expansion of terminology compared to the Arabic original - indicate that the expressions related to the names of hell and its attributes have undergone some reworking. Similar phenomena can also be noted in the versions of the same narrative attested in Aljamiado. For instance, in Ms Paris 774 - in the longest passage mentioning fire and hell - in some passages the attributes of hell have slightly been increased, but not so significantly as to prove that there has been some reworking in comparison to Ms Aitona. ${ }^{69}$

Despite their close relation to the original Arabic - and the derivation of terms, expressions and, above all, of the imagery from attestations in Islamic traditions - the texts and traditions on hell in Aljamiado versions point to a clear preference accorded to the term Jahannam to mention fire. The overall primary use of Jahannam is for instance attested in the Tafsira of the Mancebo de Arévalo, where "fire(s)" appears only to mention the punishments of hell. This is particularly evident in the chapter in which sins and punishments are described. ${ }^{70}$ The reason for this preference is probably to be found in the easier cultural identification of the thing evoked through an Islamically-connoted term rather than through a faithful translation in Spanish. This was the reason behind the use of aljanna for paradise, and of the corresponding jahannam for hell.

68 “Aitona," p. 285; “Junta 57," f. 171v: los de jahannam; cf. instead "Junta 9," p. 305: con los vasos del tormento de los de laza... de al-jahim ... i con las obras malas de los de Sa ir: "BRAH T8," p. 463: tormento de jahannam. See also "Paris 774," p. 204, “Aitona," p. 293: where one mentions the tizones de jahannam ("firebrand of the Jahannam"), the other simply uses Jahannam.

${ }^{69}$ See "Paris 774,” pp. 206-209; “Aitona,” pp. 294-296. See for instance "Paris 774," p. 206 which mentions el xuelo de jahannam, not included by “Aitona," p. 294. Both display the same alternation of fire/Jahannam in the passage, so this detail is not enough to state their preferences. See for ex. where in "Paris 774," p. 208 we find ffuego, while in "Aitona," p. 295 and "Junta 9," p. 325 we find Jahannam; but cf. "Paris 774," p. 209: ffuegos de Jahannam; “Aitona," p. 296, "Junta 9," p. 326 en-el fuego.

${ }^{70}$ Mancebo de Arévalo, Tratado (Tafsira), see on this passage pp. 288-289; Jahannam is quoted in pp. 106, 163, 183, 217, 221, 225, 262, 280, 313, 330, 377: las penas de Jahannam: p. 199; along with aljanna: pp. 176, 183, 254, 341,368. If we take a manuscript as Junta no. 3 into consideration, we can notice the alternate use of the two terms, but a predominance of Jahannam, see Kontzi, Aljamiado Texte, fuwego: pp. 431, 510, 616, 561 (con buertas); fuwegos de Jahannam: pp. 363, 445, 616, 640, 665; Jahannam: pp. 458, $592,610,664$. 


\subsection{Fire}

Despite all the cultural reasons leading to favor Jahannam rather than $a l-n \bar{a} r$, this last term occurs so often in the Qur'ān and in later Islamic and Arabic traditions and literature, that the translators of the Aljamiado texts from Arabic could not but use it. Thus, in many sources - even if less frequently - we find the simple term fuego, which is the Spanish for the Arabic al-nār, "fire." 71 It is relevant to note that sometimes it appears in different texts contained in the same manuscript, or alongside "Jahannam" in adjacent passages. ${ }^{72}$ The most typical example in this regard can be found at the end of the story of the Day of Judgment, when Muslim sinners, who are punished, ask Muhammad for intercession and fuego and jahannam are alternatively used. ${ }^{73}$ In other passages of longer stories, "fire" is used with the meaning of "hell," such as in the different versions of the story of the Day of Judgment or, for instance, where the term fuego appears together with aljanna. ${ }^{74}$ Where, for example, there is mention that those destined to paradise must be sent to paradise, while those destined to hell must be sent to hell; "hell" is referred to as fuego; 75 "fire" appears again when we find the Arabic ahl al-nār ("Those of hell") in the Aljamiado text. ${ }^{76}$ Expressions connected to fire are very rarely used to describe narrative features of hell. For instance, las puertas del fuego ("the doors

71 “Paris 774,” pp. 203, 231; “Aitona,” p. 293, “Junta 57,”f. 81v; ““'BRAH T19”,” pp. 313, 368; "CSIC XXIX" (=Ahmed Zakaría Ahmed, Edición y estudio del manuscrito aljamiado-morisco $n^{\circ}$ XXIX del C.S.I.C.), pp. 59, 70, 72, 100; “Junta 9," pp. 422, 423, 242: place of the disbeliever is hell; "ABN 614," p. 352; Vespertino Rodríguez, Leyendas aljamiadas, p. 159; "BRAH T8," pp. 467, 469-471.

${ }^{72}$ See for ex. "Paris 774," pp. 202-203, 206-11, 257-261; “Aitona," pp. 289, 293, 294296; “Junta 9," pp. 326, 329; “CSIC XXIX,” pp. 47, 106, 144-145; “ABN 614,” pp. 352, 355; "Junta 13," p. 292; Vespertino Rodríguez, Leyendas aljamiadas, pp. 200, 202, 219; "Urrea de Jalón," p. 81; Abboud-Haggar, "Ibn al-Ğazarî en la literatura aljamiado-morisca a través de los manuscritos J-LII y T-232," p. 39; "BRAH T8," p. 461; "BNM 5301" (=Labib, "Spanische Lautenwicklung und arabisch-islamischer Geist in einem AljamiadoManuskript des 16. Jahrhunderts"), pp. 72-73.

73 "Paris 774," pp. 210-214; “Aitona,” pp. 296-298.

74 “Paris 774," pp. 173,193, 206, 257, 258; “Aitona,” p. 287; “Junta 57,” ff. 104r, 152v, 166r. See also "Paris 774," p. 173; “"“BRAH T19”," pp. 292, 341, 458; "CSIC XXIX," p. 66; “Junta 9," p. 308; “BNM 4953,” p. 120; Vespertino Rodríguez, Leyendas aljamiadas, pp. 200, 219; "Urrea de Jalón,” p. 178; “BRAH T8,” p. 459. 314-316.

75 “Paris 774,” pp. 198-200; “Aitona,” pp. 290-291, “Junta 57,” f. 157v; “Junta 9,” pp.

76 "Paris 774," pp. 213-14, 221-222.

Al-Qantara XXXV 2, 2014, pp. 527-553 ISSN 0211-3589 doi: 10.3989/alqantara.2014.018 
of fire"), as found in the Qur'ān, ${ }^{77}$ or one or two doors of fire, are the only details which are actually mentioned. ${ }^{78}$

The occurrences of "fire," which are less frequent than those of "Jahannam," and also the fact that alnar is never used alongside aljanna, show that this term was used according to its predominance in the Qur'ān and in early Islamic traditions. Ignoring this feature was absolutely impossible and, for this reason, it does appear frequently, but not as much as the favorite term in Aljamiado literature.

\section{Aljamiado Translations of the Tanbihh al-ghäfilin and Other Litera- ture}

A significant reference concerning the use of these terms is also offered by the Aljamiado translation(s) of the Tanbīh al-ghāfilìn by Abū al-Layth al-Samarqandī and the Morisco literature in Latin script. As regards Samarqandī, whenever a cross-check of the Aljamiado text with the original in Arabic is possible, a number of features can be singled out. ${ }^{79}$ The title given is "Capítulo en la senblança de los del fuego" ("Chapter on the Likeness of the People of Fire"), which is slightly different from the original Bāb sifat al-nār wa-ahli-hāa. ${ }^{80}$ The Spanish is generally a faithful translation of the Arabic, even though some passages have required further explanation. For instance, the expression fuego de jahannam is provided to better explain a short report attributed to the Prophet ${ }^{81}$ or, in another

77 "Junta 57," f. 105r: about the Ramadan, when the doors of paradise are open and those of Jahannam are close, see also 111v; "Junta 13," p. 296.

78 "BRAH T19", p. 457.

${ }^{79}$ Only a few authors have discussed and compared the Aljamiado texts to the original Arabic versions, see for ex. al-Amiri, "El original árabe del tratado de al-Tafrī" frente a sus dos versiones aljamiadas," pp. 27-34.

80 "Samarqandī" (=Busto Cortina, El al-kitāb Çamarqandī. Edición del Ms. Aljamiado 4871 de la B.N.M., con un vocabulario completo y un estudio de algunos cuentos que en él aparecen), p. 3; from here onwards, the comparison with the Arabic is based on the edition of the Tanbih al-ghäfilin publ. in Casablanca, n.d., which is a reproduction of a Cairo edition. It must be underlined that the translation edited by J.C. Busto Cortina is not complete, though the three manuscripts preserving parts of it cover together the whole work, see Suárez García, "Las demandas de Hatim al-"Așam."

81 "Samarqandī," p. 30; but it appears as fuego del infierno in "Mohanmad de Vera" (=Suárez García, El tratado de materia religiosa de Mohanmad de Vera (Ms. 397 Esp. de la Biblioteca Nacional de París)), p. 83. 
case, in the Aljamiado text, we find that Mālik is referred to as Mālik el tesorero del fuego, i.e. "the doorkeeper of fire." ${ }^{82}$ Furthermore, in the long tradition describing the doors and layers of hell, the translation of the names of people destined to be punished is mostly faithful: 1) al-Hāwiya for hypocrites, people of the Table and of the Pharaoh; 2) al-Jahim for those committing shirk; 3) Saqar for the gentiles, where in the Arabic we find $a l-s \underline{a} b i$ ' $\bar{u}$; 4) Laz $\bar{a}$ for Iblìs and his followers, and the Mazdeans; 5) al-Hutama for the Jews; 6) al-Sa ir for the Christians; and 7) for Muslim sinners. ${ }^{83}$ In general, the alternation fuegoljahannam follows the occurrences of the terms in the original Arabic and, apart from the only case mentioned above, fuego always translates the Arabic al-nār. Few phenomena, such as small omissions and additions, are unimportant, and no conclusion can be drawn from them, since they could also be connected to the existence of different manuscript versions of the work of Samarqandi, and not to the translation itself. In general, Aljamiado texts are a very faithful transposition of the original text in Arabic as for contents and formal devices, with a few examples, as regards eschatology, of glosses or additions to explain the contents of the original in the new language. The Tanbih al-ghäfilin can be considered as the expression of a unique voice in the literary stratifications of the traditions and works circulating among Muslims. It undoubtedly shows a sort of higher level than the other materials diffused and as such, even though it is not a theological book but a collection of traditions, it reflects a different attitude compared to other more popular texts.

The relevance of terminological choices - and of all this discussion appears clear if we take some other later literature into consideration, for instance, the literature written in Latin script. By cross-referencing these literatures, it emerges that the conservative attitude and the preference first for the term "Jahannam," and then for "Fire," revealed by Aljamiado texts,

82 "Samarqandī," p. 32; and cf. with "Junta 9," p. 221: el porter del fuego. The text also shows the term zabaniya (referred to the angels of hell) translated as los almalakes aprecurantes, see "Samarqandī," pp. 31, 33: a los almalakes aprecurantes con-el fuego. See also where zabāniya is simply transcribed: "Junta 9," p. 321.

83 "Samarqandī," p. 31; cf. also "Mohanmad de Vera," p. 84. On the names used in the manuscripts in Arabic circulating in al-Andalus, see "Manuscrito de Ocaña" (=Hofman Vannus, Historias religiosas musulmanas en el Manuscrito mudéjar-morisco de Ocaña: Edición y estudio), intr. pp. 16-17. The same list is given in 'Abd al-Rahìm al-Qādī, Daqā'iq al-akhbār fi dhikr al-janna wa-l-nār, pp. 64-65; see a similar list in Abu-Deeb, The Imagination Unbound. Al-adab al-'Aja'ibi and the Literature of the Fantastic in the Arabic Tradition, p. 95. 
reflect a greater concern for the text, rather than the mere acceptance and subsequent adherence to the originals in Arabic. In the treatise on religious matters written in Latin script by Mohanmad de Vera, which renders the Tanbih al-ghäfilìn almost faithfully, we also find the term infierno alongside fuego, with the proper meaning of "Fire," ${ }^{4}$ and we also find the expression fuego del infierno ${ }^{85}$ Later on, the term jahanna is also used, in some cases in alternation with fuego ${ }^{86}$ while in one case infierno translates "Jahannam," for example in the expression las orillas del ynfierno ${ }^{87}$ This attitude is confirmed and verified in the treatise of Dos Caminos, where the favorite word for "hell" is ynfierno, and it appears together with "fire." 88 The tendency emerging in Mohanmad de Vera's text proves the existence of a different audience; also, the eternal abodes are referred to with less specific cultural terms and, in the Morisco texts of Aljamiado literature, they are always mentioned using Muslim names.

\section{Aljamiado Terminology and Arabic Traditions and Literature}

The use of terms relating to hell in Aljamiado literature displays specific features which have been thoroughly discussed above. A rather close faithfulness to the original Arabic sources and the history of the transmission of the copied texts - thus with no direct access to the originals prompted a polarization of the terminology around "Jahannam" and "Fire," the two major terms which translate "hell" in Muslim traditions. Aljamiado texts somehow show a preference for "Jahannam" to refer to hell, even though "Fire" is also frequently used. This appears clearly in translated texts which are supposedly more conservative, such as major literary works. "Jahannam" and other terms related to it are generally used, while the other Quranic terms can usually be found when the doors of hell

84 "Mohanmad de Vera," pp. 76, 81.

85 "Mohanmad de Vera," p. 82.

86 "Mohanmad de Vera," pp. 78, 83.

87 "Mohanmad de Vera," p. 85.

${ }^{88}$ On ynfierno: López-Baralt, Tratado de los dos Caminos, pp. 193, 338, 353: las puertas del ynfierno = p. 361 (siete), p. 365, p. 479. On the use of ynfierrno and also of gloria for paradise in "Mohanmad de Vera," see also Roza Candás and Suárez García, "Léxico religioso islámico y Cristiano," p. 240. On gloria for paradise in the Qur'ān, see in LópezMorillas, The Qur'ān in Sixteenth-Century Spain, p. 79. On Fire: López-Baralt, Tratado de los dos Caminos, pp. 365, 400, 458, 475. 
are mentioned. It seems that Moriscos preferred to use aljanna and jahannam for paradise and hell, as indicators of Islamic features in a Christian environment. It is highly significant, in this regard, that paraiso and infierno appear in other contexts but very rarely in Aljamiado literature as such. The presence of "Fire" is of secondary importance but still significant, and is strictly related to the numerous occurrences in the Arabic sources.

What is far more problematic is to ascertain if this is to be considered a particular feature of Spanish Aljamiado works, or something which could have already characterized the original Arabic versions, on which the Spanish translators relied upon. The details we can find in the translations of the Qur'ān and of the Tanbìh al-ghäfilìn are not enough to constitute evidence in this regard, although they evidently point in this direction. With regard to the other texts taken into account - since, in most cases, no direct source of translation has been discovered so far - only provisional considerations can be made, as far as Islamic literature as a whole is concerned. Islamic literature - which we only briefly discussed in relation to the expression "fire of Jahannam" - attests to the circulation of traditions using the two terms, as well as the others, in continuity with Quranic terminology. However, it is not easy to detect a specific tendency in late Islamic literary works if they are hadith-oriented, since early traditions - and, consequently, terms related to previous materials - are quoted. More specific results could be obtained by analyzing the terms used in chapter headings. However, the evidence provided by this analysis is also unreliable as, in some editions, chapter headings are added by editors, and in some early works they were added by later copyists. That being said, a few words should be added to better understand the use of the terms in relation to Islamic Arabic literature as a whole in Aljamiado literature.

Arabic works dealing with eschatology - and hell in particular - usually show a relatively larger use of the term "Fire" rather than of "Jahannam," although both appear as synonyms all over the section dedicated to the topic; sometimes, they are even interchangeable. It is quite common to find al-nār in chapter headings, and jahannam in the traditions quoted next to them, and vice-versa. Not withstanding the larger use of al-nār, literary works collecting and discussing hadiths and reports display a clear preference for "Jahannam" in relation to the physical description of hell and all the details on what it is like and what is in it. When describing its shape, its edge, its doors, its valleys, pits, rivers and anything related to it 
and its landscape, the mostly used term is "Jahannam." 89 Some sources refer to the shape of hell with the expression sifat Jahannam..$^{90}$

In other cases, when hell is mentioned in relation to the morality of the people condemned and of their sins etc. the favorite term appears to be "fire." This tendency clearly emerges above all in the organization of the materials, but it is partially verified in the reports themselves. "Fire" is mentioned when describing the food and drinks awaiting those condemned to hell, and the clothes they wear, or when describing the damned weeping in hell. In this regard, the expression ahl al-nār ("Those/The people of Fire") is emblematic of this use, since it always appears to refer to the damned and the people destined to hell. ${ }^{91}$ In the few less hadith-oriented works - which generally preserve a complete narrative rather than simply reproduce short extracts from reports handed down by previous generations - we notice that "Jahannam" is preferred. In the anonymous Kitāb al- 'azama, for instance, "Jahannam" is the favorite term, although this could be considered to be in line with the tendency mentioned above. In this work, all the descriptions represent a pictorial "geography" of hell, and thus "Jahannam" becomes the favorite reference name. ${ }^{92}$

That being said, the Aljamiado texts appear to perfectly fit the Islamic traditions, and to be in continuity with the tendencies outlined above. However, they represent a step further, just like later Muslim Arabic literature, in the simplification of terminology but also in the clear preference for "Ja-

${ }^{89}$ Asad b. Mūsā, al-Zuhd, p. 23: on awdiya and mountains of Jahannam, even though at p. 26 he mentions the serpents (hayyāt) of Fire; 'Abd al-Rahìm al-Qāḍì, Daqā 'iq al$a k h b \bar{a} r$, p. 66; Ibn Abī al-Dunyā, Sifat al-nār, pp. 18-19 on the doors; but on 35: the mountains of Fire in the title, while in traditions Jahannam is the most used term; Ibn Rajab, al-Takhwīf min al-nār wa-l-ta 'rīf bi-hāl dār al-bawār, pp. 59-130; Ibn Kathīr, Nihāyat albidāya wa-l-nihâya fi al-fitan wa-l-malāhim, p. 374, but cf. p. 379: on the walls of the Fire; al-Qurtubī, Kitāb al-tadhkira bi-ahwāl al-mawtā wa-umūr al-ākhira, II, p. 833f., p. 870f.; al-Suyūțī, al-Budūr al-sâfira fì umūr al-ākhira, p. 306f.

${ }_{90}$ Ibn Abì al-Dunyā, Sifat al-nār, p. 23f.; al-Qurțubī, Kitāb al-tadhkira, II, p. 858; Ibn Kathīr, Nihāyat al-bidāya, p. 361, but cf. p. 390: șifat al-nār; and cf. also al-Ishbīlī, Kitāb al-'Āqiba, p. 290: bāb fí șifat al-nār wa-sifat ahlihā ...; al-Suyūtị, al-Budūr al-sāfira, p. 306 .

${ }^{91}$ Ibn Abī al-Dunyā, Sifat al-nār, pp. 59, 131: on the damned weeping; Ibn Rajab, alTakhwīf min al-nār, p. 131f.; Asad b. Mūsā, al-Zuhd, p. 33f.; 'Abd al-Rahīm al-Qāđịi, Daqā'iq al-akhbār, p. 69; Ibn Kathīr, Nihāyat al-bidāya, p. 380f.; al-Qurtubī, Kitāb altadhkira, II, pp. 866f., 887-928; 'Abd al-Ghanī al-Maqdisī, Dhikr al-nār, p. 67f.: dhikr alnār wa-ahlihā; al-Suyūṭi, al-Budūr al-sāfira, p. 326f.

${ }^{92}$ See Abu-Deeb, The Imagination Unbound (including an edition of An., Kitāb al'azama), p. 95f., including names of the doors, description of the structure of hell, of its valleys, etc. Fire is found in the expression ahl al-nār: p. 126. 
hannam," which could be connected to the kind of literary material diffused..$^{93}$ In other words, this use of "Jahannam," on the one hand, reflects the necessity to characterize hell through a Muslim name - rather than through the more generic term "fire" - in a minority environment. On the other hand, it is directly connected to the type of literature translated, which is mostly made of late extended stories and traditions which show a particular interest in a long description of the visual aspect of hell. Therefore, Aljamiado texts further illustrate the tendency to privilege "Jahannam" in this kind of descriptions of hell, as already shown in hadith literature, and as further developed in late Medieval narratives on eschatology and hell.

\section{Conclusion}

Many questions emerge from the discussion on the literary sources mentioned above. The analysis of the terminology on hell in the Toledo Qur'ān and in Aljamiado literature - as well as the cross-check with other Quranic translations and Islamic eschatological literature - highlights a number of identifying features of each source, as well as the relations between them. As a general consideration, it appears evident that the Toledo Qur'ān strictly belongs to Aljamiado literature. This further confirms the opening statement about the fact that it might have been copied from a version of the Qur'ān including the original Arabic, along with the Aljamiado translation. Most likely, the one who copied it in Latin script produced a faithful transcription from the Arabic script, preserving all the features that are also displayed by the corpus of Aljamiado literature.

Another point emerging from this analysis provides further evidence on the "Islamic" nature of Aljamiado literature. Among the old judgments about its contents, there is the well-known statement by Nykl, claiming that these religious texts prove the decline of the knowledge of the Islamic faith precepts. ${ }^{94}$ This is no longer the case, and many other works of research in the last decades have underlined this. I would say that the truth is quite the reverse: Moriscos were a minority strongly concerned about the beliefs of their faith and the preservation of their literature. ${ }^{95}$ The ter-

${ }^{93}$ On a similar type of simplification, cf. López-Morillas, El Corán de Toledo, pp. 92-93.

${ }^{94}$ Nykl, "A Compendium of Aljamiado Literature," p. 29.

${ }^{95}$ See on this Barceló and Labarta, Archivos moriscos. Textos árabes de la minoría islámica valenciana. 1401-1608, p. 59 and ff. 
minology used to translate and refer to hell clearly proves this, and any difference underlines the Islamic character - not the opposite. Furthermore, if some rewritings and revisions also exist, and some of their elements are of any cultural concern, as a whole the extent of these rewritings is completely consistent with what happened to Islamic Medieval texts diffused in Arabic. Variation in wording and even in the way characters and things are identified (sinners, layers, names) do not separate Aljamiado versions from Islamic literature. In fact, it is quite the opposite: it proves that the Aljamiado versions went through the same process as Arabic Islamic literature in the same period. The reason for this is simply that, just like in other Muslim places and times, the versions in use among Moriscos displayed various attitudes and concerns, but they all reflected ways of expression already existing in the Islamic literary traditions. Although forced into a peculiar situation, Moriscos were not urged to produce different versions of their Muslim literary heritage; on the contrary, this context determined strong conservative attitudes which led to translations characterized by a marked preference for Muslim Arabic terminology.

Nevertheless, the Toledo Qur'ān and Aljamiado literature offer more opportunities for discussion, and we can push the question about their Islamic nature further. In comparison to other translations and to later literature, even produced by Moriscos, the preservation of terminology and the use of calques clearly go in this direction. Also the preference for "Jahannam"/chehannam perfectly fits this picture. However, the wider use of "Jahannam" also seems to reflect a tendency partially shown in some later Islamic literature and, above all, in later popular rewritings, where vivid and fanciful descriptions of hell rely more on the term "Jahannam" than on al-nār. Thus, if so, it is clear that the Toledo Qur'ān does not only reveal a larger use of Islamic terminology, which reflects a cultural necessity to characterize the beliefs of a minority, but also displays certain features of the Islamic literature and, consequently, of the Aljamiado texts dating to the period between the $15^{\text {th }}$ century to the early $17^{\text {th }}$ century. The use of "Jahannam" in the Toledo Qur'ān is thus strictly connected to the Aljamiado literature as a whole which, on this point, appears in perfect continuity with the coeval Islamic literature produced in other Muslim areas, not only as regards contents, but also as far as eschatological terminology is concerned. 


\section{Bibliography}

Abboud-Haggar, Soha, "Ibn al-Ğazarī en la literatura aljamiado-morisca a través de los manuscritos J-LII y T-232," Anaquel de Estudios Árabes, 14 (2003), pp. 21-29.

'Abd al-Ghanī al-Maqdisīi, Dhikr al-nār, Beirut, Dār al-Bashā'ir al-islāmiyya, 1994.

'Abd al-Rahịm al-Qāḍī, Daqā'iq al-akhbār fì dhikr al-janna wa-l-nār, Beirut, Dār al-kutub al-'ilmiyya, 1984.

Abu-Deeb, Kamal, The Imagination Unbound. Al-adab al-'Aja'ibi and the Literature of the Fantastic in the Arabic Tradition, London, Saqi Books, 2007.

Ahmed Zakaría Ahmed, Edición y estudio del manuscrito aljamiado-morisco $n^{\circ}$ XXIX del C.S.I.C., PhD Dissertation, Universidad Complutense de Madrid, 1996 (=“CSIC XXIX").

Al-Amiri, H., "El original árabe del tratado de al-Tafrī' frente a sus dos versiones aljamiadas," in Abdeljelil Tamimi (ed.), Dimensiones ideológicas y culturales de los moriscos y las politícas de la inquisición. Actes du XIIIe symposium international d'études morisques, Tunis, Fondation Temimi pour la Recherche Scientifique et l'Information, 2009, pp. 27-34.

Asad b. Mūsā, al-Zuhd, Beirut, Dār al-Fikr, 2006.

Barceló, Cármen and Labarta, Ana, Archivos moriscos. Textos árabes de la minoría islámica valenciana. 1401-1608, Valencia, Universitat, 2009.

Barletta, Vincent, Gestos clandestinos: la literatura aljamiado-morisca como práctica cultural, Zaragoza, Instituto de Estudios Islámicos y del Oriente Próximo, 2005.

Bibliander, Theodor (ed.), Machumetis Saracenorum principis, eiusque successorum vitae, doctrina, ac ipse Alcoran, Basel, n.p., 1550.

Bouras, Karima, La Wașiyya de 'Alī del Manuscrito Aljamiado 614 de la Bibliothèque Nationale de Argelia (Estudio, Edición y Materiales), $\mathrm{PhD}$ Dissertation, Universidad Complutense, 2008 (=“ABN 614").

Al-Bukhārī, Șahīh, Beirut, Dār al-kutub al-'ilmiyya, 1990.

Busto Cortina, Juan Carlos, El al-kitāb Çamarqandī. Edición del Ms. Aljamiado 4871 de la B.N.M., con un vocabulario completo y un estudio de algunos cuentos que en él aparecen, $\mathrm{PhD}$ Dissertation, Universidad de Oviedo, 1992? (="Samarqandī").

Cervera Fras, M.J. (ed.), La plegaria musulmana en el 'Compendio de al-Tulaytuli'. Transcripcion del manuscrito de Sabiñan (Zaragoza), Zaragoza, Institución Fernando el Católico, 1987 (=“Tulaytuli").

Corriente Córdoba, Federico, Relatos pios y profanos del manuscrito aljamiado de Urrea de Jalón, Zaragoza, Institución Fernando el Católico, 1990 (="Urrea de Jalón"). 
Cruz Palma, Óscar de la, La traducción latina del Corán atribuida al Patriarca de Constantinopla Cirilo Lúcaris (1572-1638), Madrid, CSIC, 2006.

Guijarro Hortelano, Emma María, La maternidad en las comunidades mudéjar y morisca según un manuscrito aljamiado-morisco aragonés. Estudio y edición crítica (Códice T-8, BRAH), Teruel, Centro de Estudios Mudéjares, 2010 (="BRAH T8").

Gwynne, R.W., "Hell and Hellfire," in J.D. McAuliffe (ed.), Encyclopedia of the Qur'àn, vol. 2, Leiden, Brill, 2002, pp. 414-420.

Harvey, Leonard Patrick, Muslims in Spain 1500 to 1614, Chicago, Chicago University Press, 2005.

Harvey, Leonard Patrick, The Literary Culture of the Moriscos, 1492-1609: A Study Based on the Extant Manuscripts in Arabic and Aljamía, PhD Dissertation, University of Oxford, 1958.

Hegyi, Ottmar (ed.), Cinco leyendas y otros relatos moriscos (Ms. 4953 de la Bibl. Nac. Madrid), Madrid, Editorial Gredos, 1981, CLEAM 4 (="BNM 4953").

Hofman Vannus, Iris, Historias religiosas musulmanas en el Manuscrito mudéjarmorisco de Ocaña: Edición y estudio, PhD Dissertation, Universidad Complutense de Madrid, 2001 (="Manuscrito de Ocaña").

Ibn Abī al-Dunyā, Șifat al-nār, Beirut, Dār Ibn Hazm, 1997.

Ibn Abī Shayba, al-Mușannaf, Beirut, Dār al-kutub al-'ilmiyya, 1992.

Ibn Abī Zamanīn, Ușūl al-fiqh, Medina, Maktabat al-ghurabā' al-athariyya, 1994.

Ibn Hazm, al-Fiṣal fi al-milal, Cairo, al-Maṭba'a al-adabiyya, n.d.

Ibn Kathīr, Nihāyat al-bidāya wa-l-nihāya fì al-fitan wa-l-malāhim, Cairo, Maktabat al-salām al-alamiyya, n.d.

Ibn Māja, Sunan, Cairo, 'İsā al-Bābī al-Halabīi, 1990.

Ibn Rajab, al-Takhwīf min al-nār wa-l-ta 'rìf bi-ḥāl dār al-bawār, Beirut, Dār alkutub al-'ilmiyya, n.d.

Al-Ishbīlī, Kitāb al- 'Āqiba, Beirut, Dār al-kutub al-'ilmiyya, 1995.

Khedr, Tarek (ed.), Códice aljamiado de varias materias (Manuscript $N .^{\circ}$ XIII de la Antigua Junta para la Ampliación de Estudios), Madrid-Oviedo, Instituto Universitario Seminario Menéndez Pidal-Universidad de Oviedo, 2004, CLEAM 13 (=“Junta 13").

Kontzi, Reinhold, Aljamiado Texte, Wiesbaden, Franz Steiner Verlag Gmbh, 1974.

Labib, Gisela, "Spanische Lautenwicklung und arabisch-islamischer Geist in einem Aljamiado-Manuskript des 16. Jahrhunderts," Vox Romanica, 26 (1967), pp. 37-109 (=“BNM 5301”).

Laureano García, Gloria S., Tradiciones musulmanas (Ms. IX de la Biblioteca de la antigua Junta para la Ampliación de Estudios de Madrid), PhD Dissertation, Universidad de Oviedo, 2008 (=“Junta 9").

López-Baralt, Luce (estudio prelim.), Tratado de los dos caminos: (ms. S2 de la Colección Gayangos, Biblioteca de la Real Academia de la Historia) por un 
morisco refugiado en Túnez, Álvaro Galmés de Fuentes (ed.), Juan Carlos Villaverde Amieva (prep. para la imprenta), Madrid-Oviedo, Instituto Universitario Seminario Menéndez Pidal-Universidad de Oviedo, 2005, CLEAM 14.

López-Morillas, Consuelo, "Aljamiado and the Moriscos' Islamization of Spain," in Mushira Eid, Vicente Cantarino and Keith Walters (eds.), Perspectives on Arabic Linguistics. Papers from the Annual Symposium on Arabic Linguistics, VI, Amsterdam, John Benjamins, 1994, pp. 17-24.

López-Morillas, Consuelo, El Corán de Toledo. Edición y estudio del manuscrito 235 de la Biblioteca de Castilla-La Mancha, Gijón, Trea, 2011.

López-Morillas, Consuelo, “The Genealogy of the Spanish Qur'ān," Journal of Islamic Studies, 17 (2006), pp. 255-294.

López-Morillas, Consuelo, The Qur'ān in Sixteenth-Century Spain: Six Moriscos Versions of Süra 79, London, Tamesis Books Limited, 1982.

Makkī b. Abī Ṭālib, al-Hidāya ilā bulūgh al-nihāya fì 'ilm ma 'ānī al-Qur'ān watafsìri-hi, al-Shāriqa (EAU), Kullìyat al-Dirāsāt al-'Ulyā wa-l-Baḥth al-'Ilmī, Jāmi at al-Shāriqa, 2008.

Mālik b. Anas, al-Muwaț̣a', Cairo, Muștafā al-Bābī al-Halabī, 1985.

Mancebo de Arévalo, Sumario de la relación y ejercicio espiritual sacado y declarado por el Mancebo de Arévalo en nuestra lengua castellana, Gregorio Fonseca Antuña (ed.), Madrid, Instituto Universitario Seminario Menéndez Pidal, 2002, CLEAM 12.

Mancebo de Arévalo, Tratado (Tafsira), Ma Teresa Narváez Córdova (ed.), Madrid, Trotta, 2003.

Martínez de Castilla Muñoz, Nuria, Edición, estudio y glosario del manuscrito aljamiado T19 de la Real Academia de la Historia, PhD Dissertation, Universidad Complutense de Madrid, 2004 (="BRAH T19").

Mauries Boumehdi, Touria, Miscelánea aljamiada narrativa y doctrinal: edición y estudio del manuscrito Junta 57 del CSIC Madrid, PhD Dissertation, Université de Toulouse-Le Mirail, 2010 (=“Junta 57”).

Montaner Frutos, Alberto, "La Aljamía: una voz islámica en Aragón,” in José Mª Enguita Utrilla (ed.), La variación lingüistica en Aragón a través de los textos, Zaragoza, Institución «Fernando el Católico», 2003, pp. 99-204.

Muqātil b. Sulaymān, Tafsīr, Beirut, Mu'assasat al-Ta'rīkh al-'Arabī, 2002.

Muslim, Șaḥ̄h, M.F. 'Abd al-Bāqī (ed.), Cairo, 'Īsā al-Bābī al-Ḥalabī, 1955.

Nykl, Alois Richard, “A Compendium of Aljamiado Literature,” Revue Hispanique, 77 (1929), pp. 1-207.

Al-Qurțubī, Kitāb al-tadhkira bi-aḥwāl al-mawtā wa-umūr al-ākhira, al-Riyadh, Maktabat Dār al-Minhaj, 2005.

Reuter, William M., Aljamiado Narratives of Muhammad's Ascension to Heaven: the Moriscos and the Mi'rāj, PhD Dissertation, University of WisconsinMadison, 2009 (Publ. UMI Dissertation Publishing, 2010).

Roth, Ulli and Glei, Reinhold, "Die Spuren der lateinischen Koranübersetzung 
des Juan de Segovia - alte Probleme und ein neuer Fund," Neulateinisches Jahrbuch, 11 (2009), pp. 109-154.

Roza Candás, Pablo, Narraciones aljamiado-moriscas en el manuscrito de Aitona, PhD Dissertation, Universidad de Oviedo, 2009 (=“Aitona”).

Roza Candás, Pablo, and Suárez García, Raquel, "Léxico religioso islámico y cristiano en dos manuscriots aljamiados," in Abdeljelil Tamimi (ed.), Dimensiones ideológicas y culturales de los moriscos y las politícas de la inquisición. Actes du XIIIe symposium international d'études morisques, Tunis, Fondation Temimi pour la Recherche Scientifique et l'Information, 2009, pp. 220-248.

Sánchez Álvarez, Mercedes (ed.), El manuscrito misceláneo 774 de la Biblioteca nacional de París, Madrid, Gredos, 1982, CLEAM 6 (="Paris 774").

Silesia, Germán de, Interpretatio Alcorani Litteralis. Parte I: la traducción latina; introducción y edición crítica, Antonio García Masegosa (ed.), Madrid, CSIC, 2009.

Starczewska, Katarzyna Krystyna, Latin Translation of the Qur'ān (1518/1621) Commissioned by Egidio da Viterbo. Critical Edition and Introductory Study, $\mathrm{PhD}$ Dissertation, Universitat Autònoma de Barcelona, 2012.

Suárez García, Raquel, El tratado de materia religiosa de Mohanmad de Vera (Ms. 397 Esp. De la Biblioteca Nacional de París), Oviedo, Universidad, 2004 (="Mohanmad de Vera").

Al-Suyūtị, al-Budūr al-sāfira fì umūr al-ākhira, Cairo, Maktabat al-Qur'ān, 1990.

Al-Tha' labī, al-Kashf wa-l-bayān 'an tafsīr al-Qur'ān, Beirut, Dār Ihyā' al-Turāth al-'Arabī, 2002.

Al-Tirmidhī, Sunan, Shākir (ed.), Cairo, Muștafā al-Bābī al-Ḥalabī, 1955-72.

Tottoli, Roberto, "The Morisco Hell: Significance and Relevance of the Aljamiado Texts for Muslim Eschatology and Islamic Literature," in Christian Lange (ed.), Locating Hell in Islamic Traditions, Leiden, Brill, 2015 (forthcoming).

Valero Cuadra, Pino, La leyenda de la Doncella Carcayona. Estudio y edición crítica, Alicante, Universidad, 2000.

Vernet, Juan, "La exegesis musulmana tradicional en los coranes aljamiados," in A. Galmés de Fuentes and E. García Gómez (ed.), Actas del coloquio internacional sobre literatura aljamiada y morisca, Madrid, Gredos, 1978, pp. 123-44.

Vespertino Rodríguez, Antonio, Leyendas aljamiadas y moriscas sobre personajes biblicos, Madrid, Gredos, 1983.

Wiegers, Gerard, Islamic Literature in Spanish and Aljjamiado. Yça de Segovia (fl. 1450), his Antecedents and Successors, Leiden-New York-Köln, Brill, 1994.

Recibido: $24 / 03 / 2014$

Aceptado: 31/07/2014

Al-Qantara XXXV 2, 2014, pp. 527-553 ISSN 0211-3589 doi: 10.3989/alqantara.2014.018 